\title{
Beneath the Visor
}

Rohan Magoon ${ }^{1} \quad$ ItiShri $^{1}$

${ }^{1}$ Department of Cardiac Anaesthesia, Atal Bihari Vajpayee Institute of Medical Sciences (ABVIMS) and Dr. Ram Manohar Lohia Hospital, New Delhi, India

J Card Crit Care:2020;4:169-170

The gurney chisselled it's way

Through the hubbub of dismay

The forlorness in those hazel eyes

Smeared my gauntlet with sweat and ice

With exiguousness in every breath

He seeks abundance in existence

He suddenly clutches my hands

Imprinting lines on my heart,

His beseech ingress my armor

While assurances cease beneath the visor

The monitors though glint

Yet reflect gloomy hint

Shriek ostentatious sound

Amidst I stand null and void

The chasm inside ripping apart

As the bulwark in me withers afar

Horrendous tales of agony and demise

Exsanguinating shackles prevent my rise

Oh I pine for my child's warmth

And miss the caresses of lover's arms

I so long to adorn ritzy dreams
Address for correspondence Iti Shri, MD, Department of Cardiac Anaesthesia, Atal Bihari Vajpayee Institute of Medical Sciences (ABVIMS) and Dr. Ram Manohar Lohia Hospital, Baba Kharak Singh Marg, New Delhi 110001, India (e-mail: iti.anesthesia@gmail.com).

And savour the solace serene

My sense fails to prevail

Raison de'tre dusty and daze

Bhagwad Gita but beckons

Selfeless 'karma' is the norm

Lost in mirage like Arjuna

Can't be chagrin to my Krishna

So Corona dare not muddle my emotion

Subservience to oath is my inclination

I am a soldier sturdy in infirmity

Pleading groans entrust my humanity

This is destiny's moment opportune

Making flowers of faith and optimism bloom

Bring back love, joy and smiles

For my honey... And those HAZEL EYES...

\section{Note}

Support was provided solely from institutional and/or departmental sources.

\section{Competing Interest}

The authors declare no competing interests.
DOI https://doi.org/ 10.1055/s-0040-1721187 ISSN 2457-0206. (c) 2020. Official Publication of The Simulation Society (TSS), accredited by International Society of Cardiovascular Ultrasound (ISCU).

This is an open access article published by Thieme under the terms of the Creative Commons Attribution-NonDerivative-NonCommercial-License, permitting copying and reproduction so long as the original work is given appropriate credit. Contents may not be used for commercial purposes, or adapted, remixed, transformed or built upon. (https://creativecommons.org/licenses/by-nc-nd/4.0/)

Thieme Medical and Scientific Publishers Pvt. Ltd., A-12, 2nd Floor, Sector 2, Noida-201301 UP, India 